mediate, in comparison with the parents, in almost all details, namely, shape of leaf-pitcher and lid, colouring, size and shape of flower (though the flower of the hybrid is inclined to be larger and more showy than the parent), and size and shape of the petals. The intermediate relation also extends to microscopic details, such as character of cells of the epidermis, number of stomata, and characters of the internal tissues.

Dr. H. W. Youngken has studied the comparative morphology, taxonomy, and distribution of the Myricacea (bog-myrtles) of the eastern United States. The author finds that the infesting organism in the characteristic root-tubercles is an Actinomyces, and he has also observed it in the cells of the fruit-wall; after the fall and decay of the fruit it will again make its way into the soil and infect roots of other Myricas. Coccus-like forms, believed to be involution forms of the infesting Actinomyces, were found in the pitted wood-vessels, and apparently indicate the pathway taken by the parasite in order to reach the fruitwall.

Miss Margaret Henderson describes the results of a comparative study of the structure and saprophytism of the Pyrolaceæ and Monotropaceæ in relation to the Ericaceæ (heaths). The author suggests that the two former families differ from the Ericaceæ only in their gradually increasing saprophytism and in those characters which go hand-in-hand with this, namely, loss of green colouring matter, reduction from shrubs to herbs, reduction of leaves to scales, increase in the number of seeds, and the reduction in their size and in the number of cells of the endosperm and embryo. Similar degradation changes occur in the orchid and gentian families, and the author therefore supports the view which would regard the Pyrolaceæ and Monotropaceæ, not as distinct families, but as representing subfamilies of the Ericaceæ.

\title{
The Claude Process for Ammonia Synthesis.
}

I $\mathrm{N}$ the issue of the Revue scientifique for May 28

M. Georges Claude gives an interesting account of his process for the synthesis of ammonia, depending on the use of pressures approaching 1000 atmospheres. The work of compression of a gas at constant temperature varies as the logarithm of the pressure, so that if the work of compression from I to 200 atm. is $2 \cdot 3$, that from $\mathrm{r}$ to 1000 atm. will be only 3 , or at most 3.5 , if the diminution of compressibility at high pressures is taken into account. At high pressures, however, the percentage of ammonia in equilibrium with hydrogen and nitrogen will be greatly increased. Claude announced in I9I7 that his experiments indicated that the yield could be increased from about I3 per cent. at $200 \mathrm{~atm}$. to more than 40 per cent. at 1000 atm., the temperature being the same in both cases. A production of 6 grams of ammonia per gram of catalyst an hour, as compared with 0.5 grams in the Badische process, is attained. Whereas it is necessary at 200 atm., employed by the Badische Co., to circulate the gas several times over the catalvst, and to separate the ammonia after each circulation, it is sufficient to circulate only three or four times at $1000 \mathrm{~atm}$. The volume of the apparatus required for the same production is only about onetenth that required at $200 \mathrm{~atm}$. pressure. The main source of difficulty in working at high pressures is the evolution of heat, which is 25 to 50 times greater than in working at $200 \mathrm{~atm}$. The difficulty is then, not to conserve the heat of reaction to make the process autothermic, as is the case in the Badische method, but to eliminate this heat. The Claude apparatus has been operated with success at La Grande Paroisse with a unit producing $\mathrm{I} \cdot 25$ metric tons of ammonia per day, and a larger unit, for
5 tons per day, with a compressor dealing with $700 \mathrm{cu}$. m. of gas per day, has recently been put into operation with success.

The percentage of ammonia after passing the catalyst is about 25 at 1000 atm., as compared with about 6 at 200 atm. The partial pressure is therefore 250 atm., as compared with about i2 atm. at $200 \mathrm{~atm}$. total pressure. The vapour tension of liquid ammonia at atmospheric temperature being from 7 to $8 \mathrm{~atm}$, it will be seen that this is negligible in the gas obtained by the Claude process, but most appreciable with the gas obtained by the Badische process. It is sufficient, in Claude's apparatus, to pass the gas through coils immersed in cooling water in order to separate practically all the ammonia, and the residual gas, after separation of liquefied ammonia, is sent directly, without further compression, to a second catalyst chamber. Three or four catalyst chambers suffice to convert the gas into ammonia. In the Badische process, on the contrary, it is necessary to wash out the ammonia with water under pressure, requiring a complicated annaratus and expenditure of work to bring the gas again to 200 atm. after mixing with fresh gas, and $\mathbf{I}_{5}$ catalyst chambers are required. It is also necessary to use heat to separate the ammonia gas from the solution so obtained, whereas in Claude's process the liquefied ammonia is merely allowed to evaporate, producing cold which can be utilised.

The Claude process, which offers great possibilities in the synthesis of ammonia and in the utilisation of atmospheric nitrogen, is to be installed in England. The patent rights have been acquired by the Cumberland Coal and Chemicals Co., who are to erect a works in the centre of the coke-oven district in Cumberland.

\section{Field-work of the Smithsonian Institution.}

THE Smithsonian Institution has just issued its annual Exploration Pamphlet, describing and illustrating its scientific field-work throughout the world during 1920. Twenty-three separate expeditions were in the field carrying on researches in geology, palæontology, zoology, botany, astrophysics, anthropology, archæology, and ethnology, and the regions visited included the Canadian Rockies, fourteen States of the United States, Haiti, Jamaica, four countries of South America, Africa from the Cape to Cairo, China, Japan, Korea, Manchuria, Mongo'ia, Australia, and the Hawaian Islands. The pamphlet serves as a preNO. 2702, VOL. 107$]$ liminary announcement of the results obtained, though many of the expeditions will be more fully described later in the various series of publications under the direction of the Smithsonian Institution.

Dr. C. D. Walcott, secretary of the Smithsonian Institution, continued his geological work in the Cambrian rocks of the Canadian Rocky Mountains in the region north-east of Banff, Alberta. The work was hindered considerably during July and August by forest fires and by continuous stormy weather in September, but the particular questions involved in the season's research were settled satisfactorily, and some 
beautiful photographs of this wild and rugged region are shown in the pamphlet. Other geological fieldwork was successfully carried on in various States of the United States by members of the staff.

In astrophysical research the institution was unusually active. Through the generosity of Mr. John A. Roebling, of New Jersey, the Smithsonian solar observing station located on the plain near Calama, Chile, was moved to a mountain peak near by, where the observations will be unaffected by dust and smoke; and a new station was established on the Harqua Hala Mountain, Arizona, probably the most cloudless region in the United States. From daily observations of the radiation of the sun at these two widely separated stations it is hoped to establish definitely the value of "solar constant" observations in forecasting weather. Dr. C. G. Abbot, director of the work, also describes the successful operation on Mount Wilson, California, of a solar cooker devised by him. With this apparatus it was possible, using onty the sun's heat, to cook bread, meat, vegetables, and preserves.

Mr. H. C. Raven represented the Smithsonian Institution on an extensive collecting expedition through Africa from south to north. Although many difficulties were encountered, among others a railway wreck in which two members of the expedition were killed, Mr. Raven shipped to the institution much interesting zoological material which was greatly needed for purposes of comparison in working up the famous Roosevelt and Rainey collections already in the National Museum. Many interesting photographs of the anima!s, the natives, and the country itself are shown in this account and in that of Dr. Shantz, who accompanied the expedition as botanical collector. In Australia a Smithsonian naturalist collected, through the generosity of Dr. W. L. Abbott, specimens of the fast-disappearing remarkable fauna of that continent, while Dr. Abbott himself secured for the National Museum a great number of plants, birds, and other natural history material in various regions of Haiti. A number of other zoological and botanical expeditions are briefly described and illustrated.

In anthropology Dr. Ales Hrdlicka, of the National Museum, conducted extensive investigations in the Far East with the objects of continuing the study of the origin of the American Indian, examining the oldest skeletal remains in Japan, furthering the interests of physical and medical anthropology in China, and studying the rapidly disappearing full-blooded Hawaians. The work was successful in every respect.

Dr. J. Walter Fewkes continued his archæological field-work on the Mesa Verde National Park, Colorado. During the field season of 1920 he excavated and repaired a remarkable prehistoric building, which he designates "Fire Temp'e" on account of the undoubted use of this structure by the Indians in connection with the worship of fire. The ruin is described and illustrated in the pamphlet.

The book concludes with numerous accounts of field-work among the American Indians by members of the staff of the Bureau of American Ethnology, Smithsonian Institution, including researches among the Hopi, the Papago and Pawnee, the Fox and Cree, and others; and archæological investigations of prehistoric aboriginal structures and dwellings in various regions of the United States.

\section{University and Educational Intelligence.}

UXFORD.-Two important elections to professorships have been made since the end of term. The vacant Drummond professorship of political economy has been filled by the appointment of Prof. David Hutchison Macgregor, Stanley Jevons professor of political NO. 2702 , VOL. IO7] economy in the University of Manchester, sometime professor of political economy at Leeds, and fellow of Trinity College, Cambridge. Prof. Macgregor is known as a writer and lecturer on industrial and philosophical questions, and has also done work in connection with the Board of Trade.

The Linacre chair of zoology and comparative anatomy, vacant by the regretted retirement of Prof. G. C. Bourne, has been filled by the appointment of Prof. E. S. Goodrich, fellow of Merton College, and hitherto professor of comparative embryology and Aldrichian demonstrator in comparative anatomy at Oxford. Prof. Goodrich enjoys a high reputation among zoologists, and his artistic attainments are also widely recognised. $\mathrm{He}$ is president this year of Section D (Zoology) of the British Association, and the address which he is to deliver at the forthcoming Edinburgh meeting is awaited by zoologists with keen interest.

The University has lately bought a large house in Mansfield Road, part of which will furnish the School of Geography with increased accommodation.

The Board of Education has at last issued the longawaited report of the Burnham Committee dealing with scales of salaries for full-time teachers in technical schools, schools of art, evening schools, and day continuation schools, in which the local education authority accepts responsibility for the salary scales. The report follows in natural sequence upon the reports of the other two Joint Committees, and is correlated especiaily with that of the Joint Committee on Secondary Schools. Teachers are graded as (I) principals, headmasters, or headmistresses, (2) heads of departments, (3) graduate assistants, (4) non-graduate assistants, and (5) instructors. For the graduate class the scale determined is $240 l$., rising to $500 l$. by annual increments of $15 l$. , and for nongraduates rgol., rising to $400 l$. by annual increments of $12 l$. Ios. The corresponding figures for women are $225 l$., rising to $400 l$. by annual increments of $15 l$, and I 77 l. Ios., rising to $320 l$. by annual increments of I2l. Ios. For male graduates in the London area the scales are increased by the addition of $5 \mathrm{ol}$. to both the minimum and the maximum, corresponding additions being made also to the other scales. In order to attract highly trained teachers to the technical service, the local education authority may raise the minimum by $25 l$. and the maximum by $50 l$. in the case of a good honours degree or its technological equivalent. Further, other additions may be made in respect of post-graduate training and posts of special responsibility. It is possible, therefore, for a graduate teacher to secure a maximum salary of $65 \mathrm{ol}$. in London and $600 l$. in the provinces, with the opportunity of promotion to the higher grades. Under such conditions a real career is offered in the service to both men and women, and the Committee is to be highly congratulated on the satisfactory completion of an extremely difficult problem. The Committee regrets that it has been unable to determine scales for the other grades of teachers owing to the many and various types of schools and the wide divergence of local conditions. Local education authorities are asked, however, to formulate suitable scales by agreement, and it is pointed out that these scales should be comparable with those adopted for similar classes of teachers in the secondary schools of the area. The adoption of the report will influence the desired development in technical and scientific education, which depends so largely on the securing to, and retaining in, the service the best type of teacher. It is in this respect satisfactory to find that technical and commercial qualifications and other experience may be regarded as the equivalent of an academic degree. 